\title{
DZIEJE PRAWA W KOŚCIELE ŁACIŃSKIM - SYNTEZA DLA EUROPY ŚRODKOWO-WSCHODNIEJ. Recenzja książki Vojtecha Vladára pt. Dejiny cirkevného práva, Praga: Wydawnictwo Leges 2017, ss. 608
}

\section{Streszczenie}

Niniejszy artykuł stanowi recenzję publikacji autorstwa Vojtecha Vladára omawiającej dzieje prawa kościelnego. Książka ta ma charakter podręcznikowy i koncentruje się na powszechnej historii Kościoła zachodniego. Sporo miejsca poświęca również rozwojowi prawa kościelnego na ziemiach, które składają się na obecne terytorium Słowacji. Jej autor jest badaczem z zakresu prawa rzymskiego i prawa kościelnego, wykładającym na uniwersytecie Trnawie.

Słowa kluczowe: prawo kościelne; historia Kościoła; chrześcijaństwo

\section{$* * * * *$}

Z zadowoleniem należy odnotować, że na rynku wydawniczym u naszych południowych sąsiadów ukazała się nakładem znanego czeskiego wydawnictwa Leges obszerna publikacja o charakterze podręcznikowym autorstwa Vojtecha Vladára, omawiająca dzieje prawa kościelnego. Książka ta koncentruje się na powszechnej historii Kościoła zachodniego, lecz

* Ks. dr hab., prof. UWM, Katedra Praw Człowieka i Prawa Europejskiego, Wydział Prawa i Administracji, Uniwersytet Warmińsko-Mazurski w Olsztynie, ul. Warszawska 98, 10-702 Olsztyn, e-mail: mieczyslaw.rozanski@uwm.edu.pl. ORCID 0000-0003-3345-1740.

** Dr hab., Instytut Społeczno-Prawny, Państwowa Wyższa Szkoła Zawodowa im. Angelusa Silesiusa w Wałbrzychu, ul. Zamkowa 4, 58-300 Wałbrzych, e-mail: pszymaniec@, poczta.onet.pl. ORCID 0000-0002-5415-9215. 
sporo miejsca poświęca również rozwojowi prawa kościelnego na ziemiach, które składają się na obecne terytorium Słowacji. Autor jest badaczem młodszego pokolenia, o uznanym dorobku z zakresu prawa rzymskiego i prawa kościelnego, wykładającym na uniwersytecie Trnawie.

Praca składa się z 20 rozdziałów, a jej treść ułożona została w sposób chronologiczny. Najpierw autor omawia podstawowe zagadnienia dotyczące funkcjonowania prawa kościelnego, daje jego charakterystykę, a następnie przedstawia jego podstawy zawarte w Starym i Nowym Testamencie oraz wskazuje, na czym polega rola tradycji kościelnej (s. 17-33). Należy zauważyć, że fragmenty te napisane zostały w sposób zrozumiały nawet dla osoby w ogóle nieobeznanej z dziedzictwem chrześcijańskim. Nie oznacza to jednak trywializowania przedstawianych zagadnień, poza tym znalazły się tam także kwestie dalekie od kolokwialnych, jak chociażby teoria ewangelii synoptycznych Heinricha Juliusa Holtzmanna $(1832-1910)^{1}$.

Po tym wstępnym rozdziale autor przechodzi już do przedstawienia rozwoju prawa kościelnego w poszczególnych epokach. Najpierw określa pierwotne prawo kościelne i zajmuje się pierwszymi trzema wiekami jego rozwoju - do czasu edyktu mediolańskiego (s. 35-83). Pokazuje, jakie były wówczas podstawy prawne funkcjonowania Kościoła, jego relację z państwem rzymskim, a także początki kształtowania się własnego prawa wewnętrznego, którego cechy zostają wskazane. Vojtech Vladár podkreśla, że pierwotne prawo Kościoła jako społeczności opierało się na elementach demokracji („duchowa demokracja”) oraz hierarchii kościelnej (episkopat monarchiczny) $)^{2}$. Wykorzystując najstarsze źródła dotyczące organizacji Kościoła w pierwszych wiekach jego istnienia ${ }^{3}$, przedstawia, w jaki sposób powstał i na jakich zasadach był oparty prymat biskupa Rzymu, a także znaczenie hierarchicznego podporządkowania w ramach biskupstwa czy w metropolii. Autor ukazuje także wykształcanie się aktów normatywnych biskupa Rzymu (dekretalia - litterae decretales) oraz pozostałych biskupów (capitula episcoporum, statuta dioecesana), jak również oma-

\footnotetext{
Zob. np. Peabody 1995, 109-116.
}

2 Por. też: Klostermann 1973, 10-11; Bielak 2010, 63-76.

3 Do nich zaliczyć trzeba Didachè, Pseudoklementyny, dzieła Ignacego z Antiochii, św. Cypriana z Kartaginy, Ireneusza z Lyonu, Tertuliana czy Hipolita Rzymskiego. 
wia źródła prawa wczesnego Kościoła - źródła patrystyczne ${ }^{4}$ oraz zbiory pseudoapostolskie.

$\mathrm{W}$ dalszej części autor zajmuje się kształtowaniem się prawa w warunkach wolnego funkcjonowania kościoła. Dlatego w pierwszej kolejności zostaje ukazane znaczenie dla prawodawstwa kościelnego pierwszych soborów, czyli pierwszego soboru nicejskiego, pierwszego konstantynopolitańskiego oraz pozostałych soborów ekumenicznych (s. 85-104). Czytelnik może się zatem przekonać, w jaki sposób zmiany sytuacji polityczno-prawnej, w której funkcjonował Kościół, przekładały się na przeobrażenia jego prawa wewnętrznego.

Dwa kolejne rozdziały opisują zagadnienia związane z cezaropapizmem. W pierwszej kolejności autor zajął się cezaropapizmem na Wschodzie (s. 105-128), wskazując, jakie było jego znaczenie doktrynalne oraz praktyczne skutki tego zjawiska, a także jakie dokumenty potwierdzały jego formowanie się. Inne podłoże miał cezaropapizm w Kościele zachodnim (s. 129-157). Tutaj wiązał się z pojawieniem się instytucji prywatnych kościołów (ecclesiae propriae), relacjami między państwem Franków i Kościołem oraz jego aparatem, a także z założeniami doktrynalnymi feudalizmu, które wpłynęły na rozwój instytucji prawnej beneficjum. Istotne miejsce w rozdziale czwartym zajmuje też zagadnienie rozwoju prawa wewnętrznego Kościoła wschodniego (zwłaszcza s. 124-128).

Z punktu widzenia konstrukcji i struktury książki ważny jest rozdział szósty (s. 159-166), mimo że pod względem objętości jest bardzo krótki. Traktuje on bowiem o związkach między prawem kościelnym a prawem rzymskim. Zawarte są tam analizy, które pokazują, na ile prawo rzymskie ma wpływ na prawo kościelne, a także jak schrystianizowane zostało prawo rzymskie (duże znaczenie w tym miał Codex Theodosianus z V w.). Jednocześnie zaś to ostatnie było pojmowane jako uzupełniające źródło prawa kościelnego (ius suppletorium et confirmatorium), przy czym taki status zaczęło zyskiwać od czasów Konstantyna Wielkiego, czyli od momentu ustania prześladowań chrześcijaństwa. Za pontyfikatu Grzegorza I Wielkiego rola prawa rzymskiego w Kościele była już ogromna, a od

4 Scharakteryzowane zostały: List Klemensa I Rzymskiego do Koryntian, Corpus Ignatianum, List Polikarpa ze Smyrny do Filipian, Epistula Barnabae, Pastor Hermae, List do Diogneta. 
wieku XII prawo justyniańskie oficjalnie uzyskało status prawa subsydiarnego ${ }^{5}$. Vojtech Vladár mocno podkreśla, że zasady prawa kanonicznego - podkreślającego przede wszystkim znaczenie prawa, a nie jego literę - wpłynęły na ukształtowanie się systemu equity w ramach anglo-amerykańskiej kultury prawnej, jak też zasad porządku prawnego Unii Europejskiej jako takiej (s. 159).

Rozdział siódmy (s. 167-181) dotyczy zbiorów zwanych dekretaliami pseudo-izydoriańskimi (Collectio pseudo-Isidoriana) oraz innych falsyfikatów, które zostały wytworzone w państwie Franków w IX wieku. Autor opisuje te dekretalia w sposób szczegółowy, dając analizę dotyczącą autorstwa, nazwy, daty powstania, treści tam zawartej i ich wpływu na system źródeł prawa kościelnego.

W rozdziale ósmym swojej książki (s. 183-204) Vojtech Vladár zajmuje się po raz pierwszy prawem kościelnym jego rodzimych ziem, ukazując pojawienie się i wzrost państwa wielkomorawskiego, działalność apostolską Cyryla (Konstantyna) i Metodego wśród Słowian, a także to, co pozostało z ich działalności nie tylko w sferze dogmatycznej i duszpasterskiej, ale również jurydycznej. Autor podkreśla, że dwaj ,,apostołowie Słowian” w pełni akceptowali prawo Kościoła zachodniego. Jednakże w swej normotwórczej działalności Metody opierał się w sporej mierze na prawodawstwie bizantyjskim, które było łatwiejsze do zaakceptowania przez miejscową elitę od tego wykształconego w Europie Zachodniej, a zarazem mogło być adaptowane do warunków prawa Kościoła zachodniego ${ }^{6}$. W ten sposób prawo obowiązujące na tym obszarze uzyskało synkretyczny charakter (s. 198-199).

Kolejne fragmenty pracy związane są z reformami kościelnymi X i XI wieku. Autor skupia się w pierwszej kolejności na koncepcji politycznej cesarstwa rzymskiego czasu Ottonów (s. 205-233), ujawniając obszary przyszłych konfliktów między władzą świecką a duchowną. Wiele miejsca poświęcono tutaj reformie Kościoła zapoczątkowanej przez papieża

Zob. też Dębiński 2010, 17-116.

6 Autor przedstawia hipotezę, że zbiór Nomokánon, oparty przez Metodego na prawie bizantyńskim, nie miał większego wpływu na prawo wielkomorawskie, a był najpewniej przygotowywany dla terytoriów znajdujących się pod wpływem Bizancjum, które książę Światopełk opanował lub miał zamiar opanować (s. 203). 
Grzegorza VII, jak również jego konsekwencjom, w krótszym i w dłuższym okresie. Ponadto mowa jest także o kwestii inwestytury świeckiej w Królestwie Węgier, w którego granicach znajdowały się obecne ziemie słowackie (s. 231-233)7. Przedmiotem rozważań w rozdziale dziesiątym (s. 235-272) jest prawo klasyczne Kościoła w czasie rozkwitu średniowiecza (ius novum medii aevi). Autor charakteryzuje najważniejsze jego elementy oraz funkcjonowanie, obrazując wpływ, jaki miały na nie takie zjawiska, jak rozwój zakonów, duszpasterstwo świeckich, wyprawy krzyżowe, filozofia scholastyczna, powstawanie uniwersytetów oraz powstanie inkwizycji ${ }^{8}$. Rozdział kończy charakterystyka prawa kościelnego na ziemiach słowackich.

Dalsze rozdziały dotyczą podstawowych pomników źródłowych prawa kościelnego i prawa kanonicznego. Tutaj właśnie znalazł się wywód dotyczący Dekretu Gracjana (s. 273-286), który został przedstawiony dość szczegółowo nie tylko po względem metodycznym, strukturalnym, ale także wpływu, jaki wywarł na rozwój prawa kanonicznego. Następnie opisana została działalność prawotwórcza Aleksandra III oraz papieży - Innocentego III i IV, dotycząca normatywnych podstaw władzy teokratycznej papieża (s. 287-306). Zgodnie z chronologią kolejny rozdział poświęcono niewoli awiniońskiej w XIII i XIV wieku (s. 307-327) ${ }^{9}$, w tym przede wszystkim - znaczeniu dokumentów wówczas wytworzonych dla rozwoju prawa kanonicznego. Wskazano tutaj zwłaszcza na podstawowe pomniki prawa kanonicznego: dekretały Grzegorza IX, zbiór Bonifacego VIII, Klementyny (Constitutiones Clementinae) i Extravagantes, zestawione później przez Jeana Chappuis.

Schizma zachodnia i jej oddziaływanie na funkcjonowanie prawa kościelnego, a także relacje między społecznością kościelną a ruchami reformacyjnymi, zwłaszcza husytyzmem są treścią rozdziału czternastego (s. 329-350). Wyjaśnione tutaj także zostało powstanie zbiorów Korpusu

W kontekście państwa polskiego zob. Skwierczyński 2016, 31-126.

8 Autor przytacza dane, zgodnie $\mathrm{z}$ którymi w procesach prowadzonych przez inkwizycję na karę śmierci zostało skazanych 2-5 \%, którzy dodatkowo odmówili wyparcia się herezji, głównie chodziło o recydywistów (s. 260). Jednakże uważamy, że - nawet w publikacji o charakterze podręcznikowym - należałoby dokładnie wskazać źródła tych informacji.

9 Zob. też: Mollat 1963; Renouard 1970. 
prawa kanonicznego. Następnie autor szeroko ukazał zagadnienie reformacji (s. 351-388). Podjęto tu ważne wątki: przyczyny oraz przebieg i skutki tego ruchu w Niemczech oraz Prusach, a także w Skandynawii, Szwajcarii, Francji, Holandii, Anglii i Szkocji oraz Rzeczypospolitej Obojga Narodów (s. 374$)^{10}$, na ziemiach czeskich i na Węgrzech, a w tym również na dzisiejszym terytorium Słowacji. Przedstawione zostały też przepisy prawa kanonicznego przyjęte $\mathrm{w}$ walce $\mathrm{z}$ reformacją oraz dotyczące odnowy wewnętrznej Kościoła.

W rozdziale szesnastym (s. 389-403) autor charakteryzuje jedno z najważniejszych wydarzeń zarówno z punktu widzenia historii Kościoła, jak i rozwoju prawa - Sobór Trydencki. Omawia elementy historyczne tego soboru, tzn. powody jego zwołania oraz przebieg ${ }^{11}$, a w sposób bardzo szczegółowy przedstawia zagadnienia zawarte w dokumentach soborowych. Pokazane zostały też cechy rozwiniętego wówczas poklasycznego prawa Kościoła (ius novissimum).

Recepcja Soboru polegała na wprowadzeniu zasad reformy katolickiej wszędzie tam, gdzie funkcjonował Kościół. Tego właśnie zagadnienia dotyczy rozdział siedemnasty (s. 405-443). Podejmując tę problematykę, autor wyraźnie położył nacisk na obszar Środkowej Europy, choć nie pominął także rozwoju katolicyzmu w Ameryce Południowej, poświęcając nieco miejsca redukcjom paragwajskim. Ponadto Vojtech Vladár podjął takie wątki, jak odnowienie życia zakonnego, znaczenie jezuitów dla rozwoju idei potrydenckich, aktywizacja katolików oraz rozwój teologii. Zajął się również funkcjonowaniem Kościoła w państwach rządzonych absolutnie, charakteryzując zagrożenia, które związane były z ideami hiszpańskiego regalizmu $^{12}$, gallikanizmu, febronianizmu, episkopalizmu w państwach niemieckich oraz józefinizmu. Po omówieniu tych zagadnień dotyczących

10 Vojtech Vladár uznaje Rzeczpospolitą za najbardziej tolerancyjne państwo ówczesnej Europy, pozostaje więc w zgodzie z twierdzeniami polskich historyków XVI wieku, zwłaszcza Janusza Tazbira. Zob. Tazbir 1973. Ponadto autor podkreśla, że tolerancja religijna była również podstawą Konstytucji 3 Maja - ustawy zasadniczej odznaczającej się chrześcijańskim charakterem (s. 413).

11 Zob. klasyczne dzieło: Jedin 1957-1961; Jedin 1967. Spośród bardziej współczesnych prac zob. też: O’Malley 2000; O’Malley 2013.

12 Autor słusznie traktuje regalizm jako kontynuację cezaropapistycznych koncepcji realizowanych w Hiszpanii od XVI w. Zob. też Ryguła 2009, 30-34. 
relacji europejskich autor pokazuje, jak wyglądała reforma potrydencka na ziemiach słowackich.

Rozdział osiemnasty (s. 445-491) traktuje o zmianach, które zaistniały w prawie kościelnym pod wpływem takich wydarzeń, jak wielka rewolucja francuska, wojny napoleońskie, Święte Przymierze, ruchy rewolucyjne i narodowowyzwoleńcze, kwestie społeczne i wreszcie pierwsza wojna światowa. W rozdziale tym pokazano, w jaki sposób reakcja na doktryny liberalizmu oraz socjalizmu kształtowała prawo kościelne, a także jakie znaczenie dla tego prawa miały Sobór Watykański I oraz odnowa tomizmu i stworzenie podwalin współczesnej myśli społecznej Kościoła za pontyfikatu Leona XIII.

Rozdział dziewiętnasty (s. 493-504) omawia wielką kodyfikację z roku 1917 - pierwszą w dziejach Kościoła obejmującą całość jego prawa wewnętrznego. Podkreślić trzeba, że sporo miejsca poświęcono pracom przygotowawczym i samemu tworzeniu Kodeksu Prawa Kanonicznego. Po ogólnej charakterystyce Kodeksu autor pokazuje, jak wyglądały statystyka i struktura tego aktu prawnego, a także w jaki sposób uzupełniano normy kodeksowe. W najdłuższym, gdyż liczącym niemal siedemdziesiąt stron, rozdziale dwudziestym (s. 505-572) znalazł się opis polityki konkordatowej Stolicy Apostolskiej w dwudziestoleciu międzywojennym, a także ukazano wpływ na prawo kościelne kataklizmów, które miały miejsce w XX wieku - komunizmu, faszyzmu, nazizmu oraz II wojny światowej. Sporo uwagi autor poświęca też działalności Kościoła w obliczu podziału świata na dwa bloki polityczne. Nie może dziwić jednak, że centralne miejsce zajmuje zagadnienie odnowy Kościoła w czasie Soboru Watykańskiego $\mathrm{II}^{13}$. Znacznie mniejszy nacisk - co może nieco zaskakiwać - położono na rekodyfikację prawa kanonicznego w 1983 r. Autor charakteryzuje także pontyfikaty wszystkich papieży XX wieku, kończąc na Janie Pawle II. Podsumowująca część odnosi się do sytuacji Kościoła w Czechosłowacji z podziałem na okres do roku 1948, a także po zamachu stanu dokonanym przez komunistów. Przedstawione zostały przepisy prawne obowiązujące przed upadkiem realnego socjalizmu, jak również podstawy prawne egzystencji Kościoła na Słowacji po uzyskaniu przez nią niepodległości.

13 Zob. także: O’Malley 1989; O’Malley 2013. 
Podział treści należy zatem uznać za logiczny i zasadniczo zadowalający. Niewątpliwą zaletą pracy jest ukazanie historii prawa kościelnego na tle rozwoju europejskiej kultury prawnej. Książka odznacza się niezwykłą przejrzystością $\mathrm{w}$ ukazywaniu nawet skomplikowanych zagadnień, a elegancki styl autora czyni lekturę przyjemną i interesującą.

Recenzowana publikacja ma charakter podręcznikowy, co oznacza znacznie ograniczony aparat naukowy, chociaż zauważyć należy, że w poszczególnych rozdziałach zawarte są przypisy odnoszące się do najbardziej istotnych aktów normatywnych, a niekiedy też do najważniejszych pozycji literaturowych. Całość bibliografii autor podał na końcu publikacji, z tym, iż zawarte są tam tylko najważniejsze pozycje i to ograniczone w zasadzie do książek. Bibliografię tę zbudowano według wzorca, gdzie najpierw wskazane zostały przepisy prawa kościelnego i prawa państwowego wydawanego w ciągu wieków, a następnie źródła nienormatywne, które miały wpływ na kształtowanie się przepisów prawa. Wreszcie zaś zamieszczono opracowania. Zaznaczyć trzeba, że większość z nich to literatura napisana $\mathrm{w}$ językach czeskim lub słowackim, co oczywiście - biorąc pod uwagę adresata tej publikacji - jest jak najbardziej zasadne. Podano także podstawowe, najbardziej znane pozycje opublikowane w języku angielskim, francuskim oraz niemieckim. Odnotować warto, że zawarta w bibliografii literatura anglojęzyczna odnosi się głównie do kształtowania się zachodniej kultury prawnej (znaczące dzieła Petera Steina, Hermanna Kantorowicza i Alana Watsona), a także historii prawa kanonicznego średniowiecza (prace badaczy reprezentujących bardzo różne podejścia metodologiczne, takich jak Michael Edward Moore, James A. Brundage, Gillian R. Evans, Brian Tierney, Anders Winroth, Robert Somerville, Wilfried Hartman i Kenneth Pennington). Dla czytelników polskich należy zauważyć, że autor zamieścił tam pracę Adama Vetulaniego $Z$ badań nad prawem rzymskiem $w$ dekrecie Gracjana (Kraków 1935) oraz tłumaczone na język słowacki monumentalne dzieło Bolesława Kumora Historia Kościoła (tom 1-8), które wydane było na Słowacji w latach 2001-2004. Kończąc niniejsze rozważania podkreślić należy, że w języku polskim jak dotąd nie powstała tak obszerna, a jednocześnie odznaczająca się porównywalnym rozmachem praca o historii prawa kościelnego, co recenzowana książka Vojtecha Vladára. 


\section{BIBLIOGRAFIA}

Bielak, Włodzimierz. 2010. „Kilka uwag na temat początków urzędu biskupiego w ujęciu historycznym". Vox Patrum t. 55: 63-76.

Dębiński, Antoni. 2010. Church and Roman Law. Lublin: Wydawnictwo Katolickiego Uniwersytetu Lubelskiego.

Jedin, Hubert. 1957-1961. A History of the Council of Trent, przekł. z j. niemieckiego Ernest Graf, t. I-IV. Edinburgh-London: Thomas Nelson \& Sons.

Jedin, Hubert. 1967. Crisis and Closure of the Council of Trent: A Retrospective View from the Second Vatican Council, przekł. N.D. Smith. London: Sheed \& Ward.

Klostermann, Ferdinand. 1973. "Demokracja i hierarchia w Kościele: przemiany w kierowaniu Kościołem”. Collectanea Theologica 43/2: 5-20.

Mollat, Guillaume. 1963. The Popes at Avignon, 1305-1378, przekł. J. Love. London: Thomas Nelson \& Sons.

O'Malley, John W. 1989. Tradition and Transition: Historical Perspectives on Vatican II. Wilmington: M. Glazier.

O'Malley, John W. 2000. Trent and All That: Renaming Catholicism in the Early Modern Era. Cambridge, Harvard University Press.

O'Malley, John W. 2013. Trent: What Happened at the Council. Cambridge, Harvard University Press.

Peabody, David Barrett. 1995. H.J. Holtzmann and His European Colleagues: Aspects of the Nineteenth-Century European Discussion of Gospel Origins. W: Biblical Studies and Shifting of Paradigms 1850-1914, eds. Henning G. Reventlow, William Farmer. Sheffield: Sheffield Academic Press.

Renouard, Yves. 1970. The Avignon Papacy: The Popes in Exile 1305-1403, przekł. D. Bethell. Hamden: Archon Books.

Ryguła, Piotr. 2009. Wolność religijna $w$ Hiszpanii na tle przemian spoleczno-politycznych w latach 1931-1992. Katowice: Wydawnictwo Uniwersytetu Śląskiego.

Skwierczyński, Krzysztof. 2016. Recepcja idei gregoriańskich w Polsce do poczatku XIII wieku, wyd. II. Toruń: Wydawnictwo Uniwersytetu Mikołaja Kopernika.

Tazbir, Janusz. 1973. A State without Stakes: Polish Religious Toleration in the Sixteenth and Seventeenth Centuries. New York: Kosciuszko Foundation. 


\section{HISTORY OF LAW IN THE LATIN CHURCH - A SYNTHESIS FOR EAST-CENTRAL EUROPE.}

Book review of Vojtech Vladár, Dejiny cirkevného práva, Leges 2017, pp. 608

\section{Summary}

The present paper reviews the book by Vojtech Vladár devoted to the history of church law. The textbook focuses on the general history of the Western Church. It also thoroughly discusses the development of church law on the territory of contemporary Slovakia. The author conducts research on Roman law and church law and is a lecturer at the University of Trnava.

Key words: church law; history of the Church; Christianity

Ttumaczenie: Daria Bębeniec 